\title{
COMMENTARY
}

\section{THOUGHTS ABOUT PROFESSOR RESNIK'S PAPER}

\section{PATRICKE. HIGGINBOTHAM ${ }^{\dagger}$}

Professor Resnik offers a compelling description of the problems of aggregating cases and compensating attorneys engaged in their resolution. ${ }^{1}$ Her responses are creative and offer fresh insights into this heavily-plowed terrain. Ultimately, in her redefinition of roles for judges and lawyers, she depends upon increased judicial regulation and oversight of attorneys. Rather than such a redefinition of roles, I prefer to accent structural changes calculated to achieve similar results by invoking attorneys' self-interest, and changes with less policing, albeit more than now exists.

In Part I, I caution against charging aggregation with problems that it exposes but does not create. In Part II, I turn to the specific recommendations of the paper.

Legislative use of private attorneys general to enforce set norms has long been a familiar part of American government. This use of private litigation as a tool of governance is justified as a powerful means of both compensating victims and achieving regulatory compliance. Yet these twin justifications are in tension because compensation costs have no internal tether to an optimal level of costs for regulatory compliance. They are related only in a rough, serendipitous way. The costs of compensating victims may be insufficient to effectuate regulatory compliance or so large as to overwhelm. It is pure happenstance if compensation and regulatory force balance out. With traditional bipolar sequential case resolution, the risk is underregulation: a gap opens between the costs of the cases and the cost levels es-

† Circuit Judge, Court of Appeals for the Fifth Gircuit.

See Judith Resnik, Money Matters: Judicial Market Interventions Creating Subsidies and Awarding Fees and Costs in Individual and Aggregate Litigation, 148 U. PA. L. REV. 2119 (2000). 
sential to the regulatory objective. ${ }^{2}$ Put another way, the system assumes the underprosecution of losses. Aggregation of cases exposes this lack of fit between costs of compensating victims and tolerable regulatory costs.

At the same time, undercompensation is not inevitably an imperfection. Regulatory goals might be frustrated by full compensation of all "victims." Note that the term "victim" derives its meaning from the norm to be enforced. Additionally, the perceived unfairness in leaving "victims" undercompensated may be ignoring the circumstance that victim status is a derivative of the norm. There is a "victim" because in proscribing conduct, a statutory scheme may create a "right" to be free of the effects of the forbidden conduct. Enforcement of norms that sweep too broadly tend to identify "victims" with little connection to the policy in play.

Private attorneys general have remained important players in enforcing policy despite the often ill-defined concept of "victim." Their usefulness in the many cases in which a rule has defined a "victim" too broadly is protected in part by the reality that the traditional model of episodic, sequentially-filed suits ordinarily does not generate claims by all "victims." When the decision to sue rests on the initiative of the "victim," many will not sue. And any unfairness of the unevenness in the awards across cases is masked.

Aggregation exposes these realities. It reveals an overly broad scope of "victims" because its efficiency in gathering claims results in fuller prosecution, possibly threatening the existence of regulated entities. Aggregation exposes inequities in recoveries across cases, creating pressure to shore up the unevenness inherent in open-ended norms. We see this result reflected in the now-familiar move from agreed specific settlement amounts to negotiated processes creating claims systems with grids and other devices-not unlike the Sentencing Guidelines. In short, many of our complaints with aggregation are difficulties that aggregation exposes but does not create.

* * *

The popularity of private litigation, particularly damage suits, as a tool for enforcing legislative policies has been sustained in part by the assumption of underenforcement. A higher level of enforcement of such policies raises the question of whether Congress intended that

${ }^{2}$ Punitive damages and other awards for more intangible losses tend to fill this gap in an equally random fashion. 
result. When a change to Rule 23 is read to facilitate large aggregations, for example, it provokes assertions that the change in the proposal is substantive and outside of the Enabling Act. Indeed, a change to Rule 23 that would discourage large classes of very small claims provokes the same assertion.

To my eyes, the culprit here is the absence of a clear statement of legislative policy. The level of enforcement is part of the package of policy choices that ought to attend the legislation. We might take a page from the recent spate of federalism disputes: a judicial insistence upon a clear statement from Congress as a condition to aggregation. Against the backdrop of our trans-substantive rules of procedure, Congress ought to decide whether to limit aggregation by caps or other devices when those procedural rules would engender a level of enforcement never intended by Congress. In short, whether and why large numbers of cases should be aggregated ought to be a considered choice reflecting its powerful substantive consequences.

One other seemingly independent legal development ought not be ignored. The bottom line, so far, of the Seminole Tribe, City of Boerne, and Alden v. Maine cases is that Congress cannot enforce its norms against States through the use of private damage suits. Simultaneously, the Supreme Court has ensured the vitality of Ex Parte Young, ${ }^{6}$ and specifically the availability of prospective injunctive relief. This leaves the enforcement of federal norms against States to suits by the United States or to the tailored injunctions of private suits. States have been freed from the bludgeon but remain under the more surgical and tailored control of injunctions. 'That this retreat from the damage remedy for private attorneys general is the product of distinct doctrinal forces does not lessen the attractiveness of increased reliance upon injunctive relief for all aggregated cases. We may see greater emphasis upon equitable remedies such as disgorgement and prospective relief. Such a move would shift the focus to the problems aggregation actually creates and away from the problems it only exposes. Perversely, however, prospective injunctive relief may have the least play with aggregated tort claims whose remedies inherently resist

${ }^{3}$ Seminole Tribe v. Florida, 517 U.S. 44 (1996).

1 City of Boerne v. Flores, 521 U.S. 507 (1997).

527 U.S. 706, 119 S. Ct. 2240 (1999).

209 U.S. 123 (1908).

${ }^{7}$ Relatedly, the use of surrogates is being challenged. Qui tam plaintiffs may not escape the state immunities from damage liability. Even the use of the bounty, as old as the Republic, is being challenged. 
consistent treatment across cases.

Class actions are only part of the phenomenon of aggregated cases. After Ortiz $^{8}$ and $A m c h e m$, ${ }^{9}$ they may play an even smaller role. Class certification under Rule 23(b) (3), where most damage suits will fall, may be most attractive when the lawyer has a contractual relationship with only a few of the victims. This lack of clients means that the lawyer needs both the opt-out requirements of the rule to round them up and the preclusive effects of a judgment. The first is obvious. The second is almost as apparent-the lawyer is selling preclusion to the defendants, who often are aggressive shoppers.

The settlement of cases in which there is a contractual relationship between the plaintiffs' counsel and each victim may proceed on an aggregate rather than an individual basis. Despite the absence of need to gather clients, plaintiffs' counsel can offer releases and even individual judgments. This is the large grey market of group settlements that is largely ignored. Indeed, the decisions in Ortiz and Amchem have cast a surrealistic shadow in that they proceed as if the class device is the only engine of settlement on an aggregate basis. That is a mistake made by rulemakers as well.

With both asbestos and tobacco cases, the practical control of large numbers of cases is concentrated in a few law firms. There is nothing clandestine or inherently sinister about these concentrations. They are predictable consequences of a free market. The gathering is by referrals of local lawyers. These firms have developed considerable information about defendants and about the science of the cases. This repository of expertise is expensive to acquire and has considerable value. Lawyers with a handful of cases see the economy of scale obtainable by referring the cases. The specialist accepts the obligations of developing a theory of liability and locating the proper defendants. The referring attorney can maintain the client contact, often assisting in developing the client history. Significantly, this aggregating of cases requires no transfer. The case need never leave its local place of filing. Settlements are negotiated for thousands of these cases on an aggregate basis-with distribution to each client according to a negotiated sum or formula. These settlements proceed with little or no judicial supervision of counsel. Rather, there is an assumption that the presence of a direct attorney-client relationship creates a private settlement. There can be problems with these set-

\footnotetext{
${ }^{8}$ Ortiz v. Fibreboard Corp., 527 U.S. 815, 119 S. Ct. 2295 (1999).

${ }^{9}$ Amchem Prods., Inc. v. Windsor, 521 U.S. 581 (1997).
} 
tlements that look much like problems attending the settlement of class actions. Yet the differences remain large in relevant ways, and they fall into a remarkably unregulated zone largely ignored by critics of the class device.

The dynamics of settlement between these two types of aggregated cases differ at bottom. There is an attorney-client relationship with each victim, however attenuated in fact, in one set and not in the other. Few of the cases can be tried on an aggregated basis, and putting those cases aside, the whole issue is one of settlement. It is assumed that without an attorney-client relationship, the judiciary is required to superintend. Indeed, the Ninth Circuit recently observed in deciding a dispute over attorneys fees:

The supervisory power of the district court affords a mechanism for assuring loyal performance of the attorneys' fiduciary duty to the class ... [b]ecause the district court had the authority and duty to pass upon the fairness of the attorneys' fees settlement independently of whether there was objection, [and] we need not decide whether the objector had standing. ${ }^{10}$

Just as Professor Resnik urges ought to happen, the court offered itself as a cure for the absence of a private attorney with an attorneyclient relationship with a victim, whose compensation is being reduced to pay the lawyers she did not hire.

All of this cautions that a constant vigil is required in this fieldever watchful for the real culprits and ever seeking to know what's really going on. I turn to the questions of managing costs with aggregated cases.

\section{II}

According to Resnik, aggregate litigation is a good thing, whether in the form of class actions, MDLs, bankruptcy, or other informal groupings. Such litigation (1) allows courts to handle a greater number of disputes at decreased unit cost, ${ }^{11}$ (2) enables less injured parties to seek redress who otherwise might not be able to, ${ }^{12}$ and (3) increases "inter-litigant equity" by standardizing results for similarly situated plaintiffs. ${ }^{13}$

${ }^{10}$ Zucker v. Occidental Petroleum Corp., 192 F.3d 1323, 1327-29 (9th Cir. 1999).

"I See Resnik, supra note 1, at 2149 (noting that concerns about "waste and inefficiency" led to the enactment of the MDL statute).

${ }^{12}$ See id. at 2146-47.

${ }^{13}$ Id. at Part III.C. 
Along with such possible advantages, the growth of aggregate litigation has also resulted in the problem of how to compensate attorneys properly who conduct such litigation. To Professor Resnik, this is an important question because aggregate litigation is a kind of public subsidy. ${ }^{14}$ The compensation of attorneys directly affects how that subsidy works in practice. At the moment, the payment of attorneys' fees in class actions is largely unregulated. In Resnik's view, because judges authorize these payments, judges are the allocators and purchasers of legal services who affect how the public subsidy of aggregate litigation functions. ${ }^{15}$ Historically, judges have been hesitant to make substantive decisions in this field. More generally, the Court has also said that judges should not be the ones making decisions as to which types of cases are deserving of subsidized treatment. ${ }^{16}$ Recently, however, in Amchem and Ortiz, the Court has stated that judges must pay for "process" in order to have legitimate mass tort settlements.

Professor Resnik's main conclusion is that the very nature of aggregate litigation creates a situation in which the compensation of attorneys must be regulated. A primary reason for this is the shifting alliances which occur, for example, in the context of mass tort cases, in which parties change their alignments at various stages of litigation. Moreover, by its very nature, aggregate litigation results in the vast majority of plaintiffs never taking an active part in the litigation. As such, their interests can be shortchanged. Professor Resnik concludes that in the context of aggregate settlements, "consent by . . . lawyers no longer suffices as a proxy for legitimacy."

She believes that there is little way around this problem without some new forms of regulation and disclosure. Some of her potential proposals include the following: (1) require court disclosure of all agreements in which attorneys representing different subclasses agree "on the side" to make payments which are not part of the settlement; ${ }^{18}$

${ }^{14}$ See id. at 2146-47 (discussing how the class action mechanism provides incentives to lawyers who represent small or poor claimants).

${ }^{15}$ See id. at 2127-29.

${ }^{16}$ Compare Resnik's comment:

Return also to Alyeska Pipeline Service Co. v. Wilderness Society and the Court's ruling that judges should not select categories of cases for which to require subsidies. My argument is that these premises have been overruled in practice because aggregate litigation unavoidably puts judges into such a position, [and] that judges cannot ignore these consequences of the aggregates they participate in creating....

Id. at 2163.
${ }^{17}$ Id. at 2169.
${ }^{18}$ See id. at 2185. 
(2) employ public attorneys to aid judges in assessing the fairness of proposed settlements and other inquiries which at this time fall on the litigants to prove; ${ }^{19}$ (3) charge the costs of this extra process against the plaintiffs or the public, all of whom benefit from the use of aggregate litigation; ${ }^{20}$ (4) establish public agencies to help deal with claims; ${ }^{21}$ or perhaps (5) use private contract law to enforce privately arranged settlements. ${ }^{22}$ Most importantly, Resnik envisions a "transparent independence" by which judges remain independent and do not favor certain attorneys or types of cases, but instead obtain the process they need in order to further the goals of the civil justice system. ${ }^{23}$

The basic premise justifying Resnik's call for regulation appears to be that aggregate litigation inherently creates conflicts of interest which cannot be removed through other structural means and thus must be regulated. To see why this might be so, consider an imaginary mass tort in which liability runs into the billions of dollars across hundreds of thousands of plaintiffs, but in which injuries vary from the trivial $(\$ 100)$, to the significant $(\$ 10,000)$, to the enormous $(\$ 1,000,000)$. A class containing all of these plaintiffs would suffer intra-class conflicts and a single lawyer could not provide adequate representation in a settlement. There would be large pressure upon the lawyer to favor one set of claims over another in an effort to achieve a settlement. Nor will subclassing by magnitude of injury end all chance for collusion. Any one of the classes may threaten to impede settlement, unless paid a premium.

Finally, even a single class with complete homogeneity among its members is not free of a risk of collusion between the plaintiffs' attorney and the defendants: if the size of the class is large enough, the precise recovery for each plaintiff is submerged in the large aggregate numbers which heavily influence the fee. ${ }^{24}$ Yet aggregate litigation invariably means that the true client is not able to audit the lawyer, and the lawyers remain unaudited except for the court's supervision. Without additional process and disclosure, Resnik's argument goes, judges cannot set fees appropriately or determine the fairness of pro-

\footnotetext{
${ }^{19}$ See id. at 2190-92.

${ }^{20}$ See id at $2190-91$.

21 See id. at 2192.

${ }^{22}$ See id. at 2158-59.

${ }^{23}$ Id. at Part V.
}

24 See id. at 2168 ("[A]n 'enormous fee' can 'relax' the 'zeal for the client." (quoting Ortiz, 119 S. Ct. at 2317 n.30)). 
posed settlements.

I agree with Professor Resnik's push for additional mandatory disclosure regarding side deals or any other agreements which indicate collusion. After all, such disclosure would entail little additional cost. I also think, however, that there are cheaper structural mechanisms that treat collusion which do not require adding yet another layer of lawyers and judicial oversight to the task of determining lawyers' fees.

Professor Resnik often states that the "economic value" of a settlement does not suffice as the sole proxy for determining how lawyers should be compensated. While that sounds good-no one wants to think that money is everything-I am not sure what a complete substitute would be. I think Resnik wants to capture the value that aggregate litigation provides to the civil justice system in her calculation. I am not convinced of the relevance of this to setting attorney fees, however. Every settlement (or case that leaves the system) also benefits the civil justice system in unmeasured ways, but we do not attempt to capture those values in any measure. ${ }^{25}$ In other words, I am concerned about the cost of "additional process," and would strive to find simple, cheaper methods which at least structurally would be fair and still promote the values Resnik wants the civil justice system to possess.

Resnik's recommendations direct our attention to legitimate concerns, but the contingent fee or percentage of the common fund method still has desirable qualities, both in its simplicity and because it generally aligns incentives. At the same time, I would give less weight to the amount of created "funds" and focus upon appropriate compensation for skill, time, and risk, with risk meaning actual risk. Fees should reflect the reality that few large sets of cases can be tried, and that settlement is the only realistic means of resolution on an aggregated basis. The risk of zero payment is small. This blend ought to better reflect the value of the attorney's service. The contingency fee minimizes needless work and ensures aligned interests, at least as long as a lawyer represents only a defined subclass which has no intra-class conflicts and is paid only from that subclass's recovery. ${ }^{26}$

Collusion is preventable. We might consider disallowing settlements that involve multiple subclasses of plaintiffs and multiple defendants-in essence, mandated severance of subclasses after pretrial

${ }^{25}$ I put aside the reverse-a user fee imposed by the court upon counsel for providing the support, facilitating-even "brokering the deal." One wonders which way the debt ought to run.

${ }^{26}$ Unless, of course, the recovery is simply so large that zealous representation evaporates. See supra note 24. 
discovery. In such circumstances, individual subclasses would not be tried or settled in conjunction with other subclasses. Only during pretrial would the subclasses be treated as one, and that may be unnecessary to coordinated discovery.

Settlements would again be bipolar or move in that direction. The result, however, would require that defendants negotiate multiple settlements. Defendants might not obtain a "global" settlement if only two of the three subclasses can be settled on their own. Of course, if one of those classes cannot be settled, it may simply show a disparity between the various valuations of what those claims are worth.

"Subclass severance" offers a smaller target to the objectors, except for limited fund cases. When defendants' resources are inadequate, subclasses may be at odds. That problem is not peculiar to aggregate litigation, although it is exacerbated by it. In that case, given the present limits of Rule 23(b) (2), bankruptcy law must solve the problem if for no better reason than its own accepted culture of rough justice.

This said, I would not attempt to form rules of management for trial judges. The variety of the cases is large, and the variety of judicial responses equally so. Ultimately there is no substitute for a trial judge's hard look and, failing that, appellate intervention. The cold reality is that most problems will be solved if the trial judge takes hold. That does not include handing off the case to a magistrate judge with occasional checks into its "progress." Nor can manuals and lists do the job. The judicial role must expand with the relaxing of the adversary contest on request for approval of a settlement. That is the box we put ourselves in as we move from the traditional roles of refereeing bipolar cases.

Professor Resnik is troubled by the idea that lawyers for different subclasses might receive different amounts under a scheme which bases payments only on a percentage of the funds recovered. Yet, as she accepts, paying all lawyers from the same fund reintroduces problems of collusion.

In her example, a Fen/Phen settlement might pay $\$ 30-\$ 60$ per member to one set of claimants and hundreds of thousands of dollars per member to another set of claimants. ${ }^{27}$ Unless we know the sizes of these classes and the strength of their claims, however, it is not clear that to apply a $20 \%$ recovery fee to both classes is inherently unfair. The $\$ 30-\$ 60$ class might well be one thousand times larger than the

${ }^{27}$ See Resnik, supra note 1, at 2171. 
other class, and/or it might be a much easier class to settle. As such, I am persuaded that the best solution is simply a contingent fee capped by a judicial limit whereby the fee must in any event be reasonable and the cap rests heavily upon the courts' assessment of the risks of the case, its complexity, and the lawyer's creativity in response, as well as the time and efforts required. This assumes that subclasses are separately represented.

Subclassing and then deciding which lawyers are to represent which subclass pose a more difficult problem. One might allow the contending lawyers to bid. There may be other solutions as well.

\section{III}

The most important contributions of Professor Resnik's piece are its implicit valuation of settlement as a desirable end to litigation and its exemplar of creativity. After imagination has run free, we must anchor with a never changing goal-ensuring adequacy of representation. While Professor Resnik's piece is facially about attorneys' fees in the context of aggregate litigation, the theme of adequate representation pervades throughout and adequate representation is the touchstone. As Resnik notes after discussing the fundamental problems of aggregation, later summarized as "representational integrity and equitable distribution, ${ }^{28}$ one possibility is that "judges could try to alleviate the difficulties by offering only adjudication. ${ }^{29}$ That is not a bad thing. A trial is no failure. Keep in mind that large aggregations of cases can seldom be tried; that absent settlement, trials must be of much smaller units. But settlements of aggregated cases remain possible and may be easier without class certification, putting aside consumer cases aggregated because the damages of a single class member may not justify a separate suit.

I return to where I began. Much of our difficulty is with the use of private damage remedies to achieve regulatory compliance with broadly stated norms. The aggregation of claims so changes the level of enforcement that courts might consider invoking a form of the doctrine of clear statement as a condition to such group resolution. Equally, the judiciary must be aware in handling these cases that procedural mechanics, such as MDL treatment and class certification, are not neutral forces; and that concentrations of control over large inventories of cases may be no more than the work of the market. Re-

\footnotetext{
${ }^{23}$ Id. at 2161.

${ }^{29}$ See id. at 2159.
} 
gardless, all are attended by large substantive consequences.

Courts are not probing adequacy of representation. Yet it is the linchpin for all settlements. It follows that compensating counsel and policing their conflicts are critical and interacting components. Relatedly, courts ought to be more cautious in accepting both the claimed amount of the fund created and its role as a proxy of the benefit conferred by the lawyers. This is prevalent in our legal culture where lawyers are paid enormous fees as a percentage of recovery and when the largest determinant of the level of the settlement or award is not the counsel's work and skill, but rather the nature of the injury suffered by the plaintiff. Accordingly, mechanical legal toleration of private arrangements between lawyer and client ought not be the practice. At the least, it has little place when the private attorney is handed the mantle of private attorney general and has no direct relationship with the "client." We should not pay by the size of the herd when the courts and natural terrain conducted the roundup. 
$* * * * * *$ 